\title{
A tanítóképzés történetei az 1918-1919-es forradalmak idején
}

Donáth Péter Pedagógusok az 1918-1919. évi politikai forgószélben. Tanitóképzók a forradalmak, az idegen megszállás és az ellenforradalmi számonkérés idején.

Trezor Kiadó, Budapest, 2020.

ISBN 978-963-8144-53-9

https://mek.oszk.hu/20100/20126/20126.pdf

\section{Kolosai Nedda}

Eötvös Loránd Tudományegyetem Tanitó- és Óvóképző Kar Neveléstudományi Tanszék

\section{A tanítóképzés történetei az 1918-1919-es forradalmak idején}

Örömmel adjuk hírül, hogy megjelent Donáth Péter legújabb könyve. A szerző az MTA doktora, az ELTE TÓK professzor emeritusa a jelentős terjedelmü, 518 oldalas, közel 42 szerzői ívnyi kötetet az Eötvös Loránd Tudományegyetem Tanító- és Óvóképző Karának 150. évfordulójára írta. Az évfordulóra szerencsésen elkészült a 15 éves kutatásban született, 29 levéltárban és könyvtárak sokaságában folytatott munka eredményeként, szisztematikusan összeállított, gondosan megírt kötet.

A könyv fejezetei önálló tanulmányokként is érthetőek, elektronikus eszközökkel is könnyen megtalálhatóak, témák, személyek, intézmények szerint egyaránt kereshetőek a szövegek. Természetesen, ahogyan a Szerző az Elöszóban idézi: Pro captu lectoris habent sua fata libelli - a könyvek sorsa azoktól függ, akik olvassák őket, most tehát már Öntől, kedves Olvasó!

Donáth Péter célja munkájával megérteni és megértetni. Szeretné leírni, megmutatni a kort, amelyet felidéz, ezért a történetek szereplőit magukat hagyja saját szövegeikkel megszólalni. Módszerével, a dokumentatív, elbeszélő módszerrel alapvetően a hatóságoknak írt feljelentéseket tartalmazó levelekkel, a forradalmak utáni kihallgatások jegyzőkönyveivel, a korszak különböző helyi lapjainak felkutatásával láttatja, teszi élővé a vizsgált korszakot, benne a tanítók, a tanítóképzés sorsát.

A Szerző érdeme, hogy olyan vizsgálati anyagokat kutatott fel és mutat be, egy olyan különleges dokumentációt tár fel, amellyel másutt nem találkozhatunk. A könyv öt fejezetre bomlik, melyek a forradalmak előzménye- 
it és utóéletét taglalják a történetek tartalmi vonatkozásai szerint, valamint időrendben. Az első négy fejezet a történeti eseményeket láttatja, az ötödik fejezet egyéni sorsokat, egyéni életpályákat elemez.

Az első fejezetben a tanítóképzéssel kapcsolatos tervek, kulcsmozzanatok alakulását rajzolja meg 1916 és 1919 között, különös tekintettel az Öszirózsás forradalom időszakára. Az események és bemutatásuk, a tanítóképzők épületének, tárgyainak sorsa szorosan összefügg a háborús helyzettel.

A második fejezetben a tanítóképzés ügyét, a tanítóképzők tanárait és diákjait érő kihívásokat mutatja meg a helyzetek árnyaltságát érzékenyen és elemzően láttatva. Kiemelt figyelmet fordít itt is a kisemberekre, akik képesek voltak a Közoktatásügyi Népbiztosság tanítóképző ügyosztályát úgy irányítani, hogy tompítsák a Tanácsköztársaság általuk nem akceptálható intézkedéseit.

A harmadik fejezet a tanítóképzők helyzetét mutatja meg az 1918-1920 közötti időszakban. Plasztikusan festi meg azokat a drámákat, melyek a háborús környezetből, az idegen megszállásból, a járványokból adódóan alakultak ki. Originális és hiánypótló ez a fejezet a korszakot bemutató írások között.

A könyv harmadik fejezete az idegen impérium alá került országrészeken maradt tanítóképzők sorsát tárgyalja: a román, a csehszlovák, valamint a szerb megszállás területeinek képzőit. Gyakorlatilag minden iskolát, kollégiumot kifosztottak, nem egyszer a hallgatókat és a tanárokat is bántalmazták a megszálló katonák. Mindig megmutatja az egyéni sorsokat az intézmények helyzetével párhuzamosan. A budai állami tanítóképző és az Országos Izraelita Tanítóképző internátusának megpróbáltatásairól külön alfejezet számol be.

A negyedik fejezet fókuszában a tanítóképzős diákok állnak. Szervezkedéseikkel a forradalmak alatti tevékenységeikkel, aktivitásaikkal, majd mindezek későbbi drámai következményeivel szembesít a fejezet. Amikor a forradalmak korszaka lezárult, azt a világnézeti-politikai szelekciót, melyet a Tanácsköztársaság hirdetett, keresztény-nemzeti elvárások mentén alakuló szelekció követte. Donáth Péter a következőképpen foglalja össze ezt az időszakot: „Közös volt bennük, hogy megtagadták a pedagógusok jogát az autonóm értékválasztásra, $\mathrm{s}$ a maguk vélt igazságát kirekesztő módon akarták az egész népoktatásban, s azon belül a tanítóképzésben érvényesíteni." (Donáth, 2020. p. 209).

A kötet legmarkánsabb részét kitevő ötödik fejezet a tanítóképzős tanárok és tanítók forradalmak alatti szerepvállalását, majd ennek következményeit idézi fel. Elképesztő mennyiségű esettanulmánnyal dolgozik, mintegy mintázatokba sorolja a történeti idő résztvevőit jellemvonásaik, cselekedeteik alapján. Így ismerkedhetünk az alkalmazkodókkal, illetve azokkal, akik nem értették meg az idók szavát. Elénk lépnek a kötél nélküli kötéltáncosok, az átmeneti útitársak, a látszólag alkalmazkodók, az öszintén csetlö-botlók.

A száz évvel ezelőtti emberi sorsok filmszerủen villannak fel az olvasó előtt, elkerülhetetlen a magunkra ismerés. Az egyéni sorsok természetesen 
ágyazódnak az őket fojtogatóan körülölelő szűkebb és tágabb társadalmi valóságba. A Szerző különösen gondosan ügyel arra, hogy az egyházi és az állami tanítóképzők sokaságának történeteit egyenrangúan mutassa meg. Szintén figyelmes arra, hogy a vidéki képzők és a budapesti tanítóképző történetei egyaránt megjelenjenek. Természetesen a 150 éves budai tanitóképzö és igazgatója valamennyi fejezetben megjelenik, tárgyalásra kerül.

Legérdekesebbnek mégis a kötetzáró megjegyzések tűnnek, egy széleslátókörü, nagyon tapasztalt, a történeti kutatásban elkötelezett ember izgalmas összegzései, tovább-gondolásra, további gondolkodásra késztető öszszegzések.

Dontáth Péter könyvének tanulmányozásával könnyen beláthatjuk: sajátos módon mindannyian részesei lehetünk, részesei vagyunk a történeti diskurzusnak. Szükség van a történetírásban is empátiára, egy történeti folyamat minden résztvevőjének szempontjait, mozgatórugóit, érzésvilágát izgalmas folyamat megérteni. Ahogyan Donáth Péter fogalmaz, különösen igaz ez a legneuralgikusabb pontokon. A perspektívaváltás képességére, fontosságára tanít Donáth Péter könyve, -ahogyan a pedagógia és a pszichológia teszi- olyan stílusban, mellyel garantálja, hogy mindig, minden időben elővehető, nem megy majd ki a divatból, mondhatjuk: időtálló. Méltó és szellemes ünneplés ez a könyv az Eötvös Loránd Tudományegyetem Tanító- és Óvóképző Karának, azaz a budai tanítóképzőnek 150 éves évfordulóján.

Kolosai Nedda: https://orcid.org/0000-0001-7932-4443 